\title{
AN ODD HIBERNACULUM
}

\section{By H. ElLiotT McCluRE}

It is well known that birds' nests, mice nests, loose bark, and other hiding places serve as hibernacula for numerous insects, but the winter inhabitants of a bald faced hornet's nesit, Vespa maculata Kirby, were surprising.

On March 4, 1933 in the Brownsfield woods, an oak-maple woods near Urbana, Illinois, a large Vespa nest, forty feet above the ground, was discovered on a limb of a sugar maple tree. It was secured and removed to the laboratory for examination. At the time it was taken the temperature was $2^{\circ} \mathrm{C}$.

The nest was 32 centimeters wide and 45 centimeters long with 13 layers of paper on the outside and six tiers of cells. It weighed 407 grams. The opening was not at the bottom, but several centimeters up on the side. Below this hole in the bottom of the nest was a sort of graveyard. 100 dead adults were massed there and of these the sex of 52 was identifiable. They were all males. Of the 2720 cells in the six tiers 165 were still capped and contained pupae or adults and there were 30 dried and shriveled larvae in uncapped cells.

Soon after the hive was brought into the warm laboratory a rustling was noted thruout it. Upon tearing it apart 65 cockroach nymphs, Ischnoptera pennsylvanica (De Geer), were captured. They were hiding in between the layers of paper. Besides these, three spiders (Philodromus pernix), two spiders (Drassus, immature) and six undetermined mites were found. Thus there were 76 arthropods hibernating in these quarters. Probably the roaches came to the nest for the food available and may have been there before the winter set in. The spiders probably moved in with the advent of cold weather. The rôle played by the mites was not determined. 

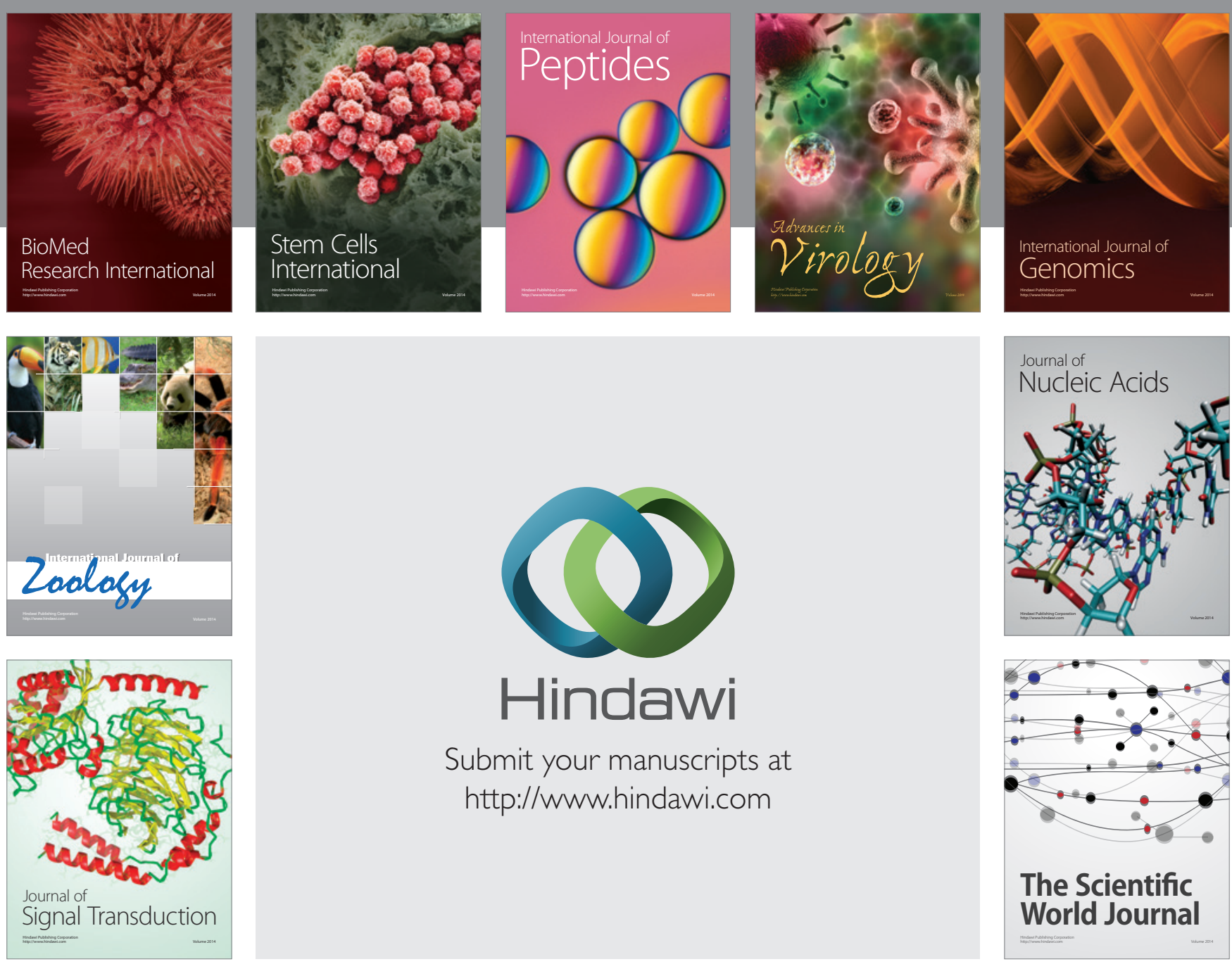

Submit your manuscripts at

http://www.hindawi.com
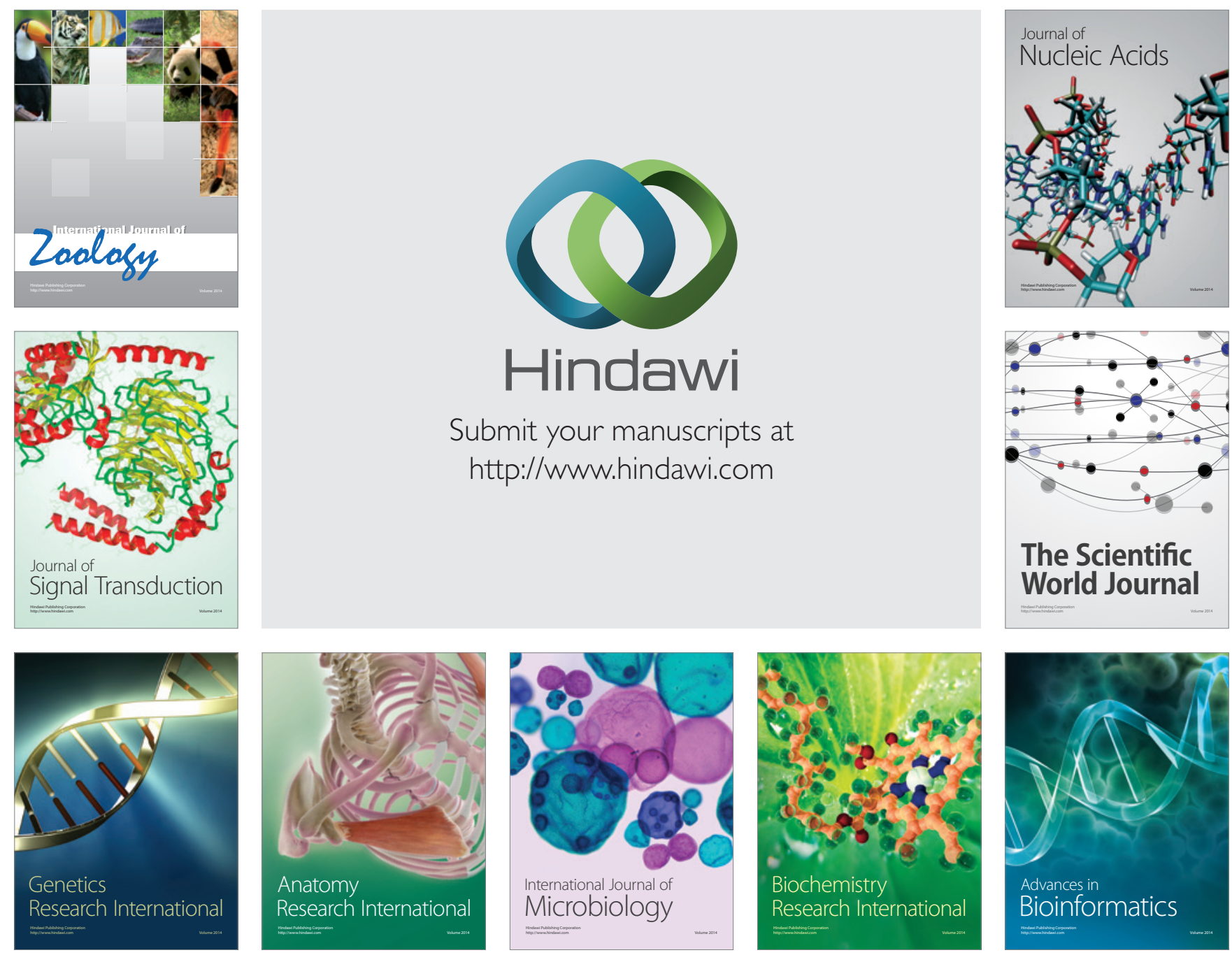

The Scientific World Journal
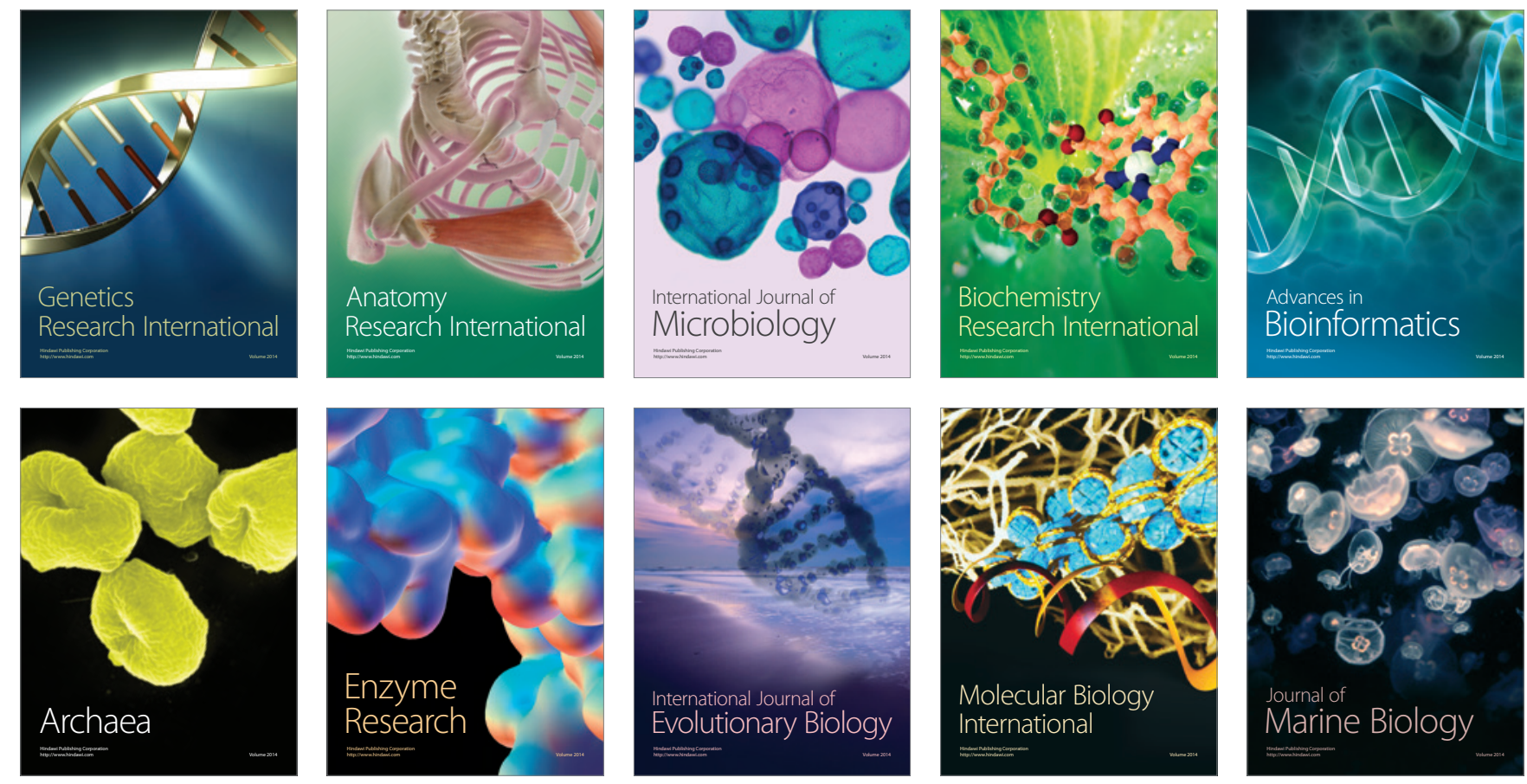